\title{
DEVELOPMENT OF THE EDUCATION PHENOMENA IN THE INTERNATIONAL LAW
}

\section{Hromovenko K. V.}

\section{INTRODUCTION}

Defining the content of international standards for the right to higher education has become a very important issue of domestic legal doctrine. At the same time, the relevant scientific analysis cannot be complete without the development of modern mechanisms in the field of education, beginning with ancient times and up to the international law of the classical period, which is a relevant objective of this research.

To achieve the objective, the reflection of educational issues in treaty acts and interstate interaction mechanisms of the Antiquity period, in the supranational legal regulators of the Middle Ages should be researched with particular attention to sources applicable to the territory of modern Ukraine. Among contemporary authors, B.V. Babin, M.V. Boromensky, V.G. Butkevich, A.I. Dmitriev, V.V. Mytsyk, etc. gave attention to the aspects of pre-classic international law. At the same time, educational matters were hardly raised.

The issue of the realization and protection of educational rights has become a significant issue in interstate dialogue a long time ago. At the same time, general archaicism and the irregularity of the system of international relations of the Ancient World and the Middle Ages could not but affect the format of reflection of relevant problems in the primary sources, many of which have not reached the present. However, it should be noted that education and enlightenment issues have already been raised in the activities between the polis unions of Ancient Greece, such as the symmachy and the amphictyony.

According to T.P. Yevseyenko, symmachies as political unions of Greek poleis generally led to the hegemony of one of them in this interstate union. Such hegemonic symmachies facilitated the creation of conditions for the development of various forms of cooperation between different poleis and led to the gradual introduction of standards of a hegemon polis in all spheres of public life. For instance, within the scope of the activities of the First Athens Maritime Union (Delos symmachy), more than 20,000 Athenian citizens were sustained by the contributions of union poleis and general duties $^{1}$. Of course, this has facilitated the spread of the standards of youth treatment, public education introduced by Athens to other symmachy poleis.

${ }^{1}$ Евсеенко Т П. От общины к сложной государственности в античном Средиземноморье / Тимур П. Евсеенко. - СПб. : Юрид. центр Пресс, 2005. - С. 127. 
Amphictyonies were also important for the formation of political contacts in the fields of education, youth, sports, and culture as religiouspolitical unions of the states of Ancient Greece. Karl J. Beloch concluded that the amphictyonies formed to coordinate religious issues subsequently extended their competence to a wide range of social relations. Specifically, within the Delphi-Thermopolis amphictyony, which was key to Ellada poleis, the issues of the arrangement of sacred sites and events, games, etc. were discussed; this approach is also endorsed by contemporary authors ${ }^{2,3}$.

Similar issues were reflected in the peace treaties; so in the Peace of Nicias agreed in 421 B.C. between Athens and Sparta, a separate solution to the issue on the rights of the Delphi Temple, which at that time played the part of a key educational institution, was specifically envisaged. Impact on the humanitarian powers of the symmachies and the amphictyonies was also foreseen by the Peace of Antalcidas, agreed in 387 or 386 B.C. between Sparta and a coalition of Greek poleis with Athens and Thebes in the forefront ${ }^{4}$.

In the international treaties of Ancient Rome, humanitarian issues were extremely limited. However, in the Treaty of Cassius between the Roman Republic and the Latin League (493 B.C.), mentioned by Dionysius of Halicarnassus, the private rights of Latins and Romans were envisaged, which certainly encompassed both cultural and educational rights ${ }^{5}$. Aspects of the status of Athens as a key educational center of international importance were also raised in the Treaty of Dardanos (85 B.C.) between Rome (Lucius Cornelius Sulla) and Pontus (Mithridates VI) ${ }^{6}$.

Subsequently, the right to preserve one's cultural identity, particularly religious, which encompassed the right for an appropriate educational and enlightenment activities, was reflected in the treaties between the Muslim and Christian countries in the period of Arab conquest. In particular, it is the Baqt treaty, which was agreed by the King of the Nubian State of Makuria and the Governor of the Umayyads in Egypt, Abdullah ibn Said ibn Abi Sar, in 637 A.D.; this act, among other, regulated the educational rights of the Arabs

${ }^{2}$ Белох К. Ю. Греческая история в 2 томах / Карл Ю. Белох ; пер. с нем. М. О. Горшензона ; под ред. Ю. И. Семенова. - М., 2009. - Т. 1: Кончая софистическим движением и Пелопоннесской войной. - С. 242.

${ }^{3}$ Щокін Ю. В. Міжполісні й міжплемінні союзи Стародавньої Греції VI-IV століть до н. е. / Ю. В. Щокін // Теорія і практика правознавства. - 2016. - Вип. 2 (10). - С. 5.

${ }^{4}$ Сергеев В. С. История Древней Греции ; изд. третье, перераб. и доп. / В. С. Сергеев ; под ред. В. В. Струве, Д. П. Каллистова. - М. : Изд-во восточной лит-ры, 1963. - С. 218.

${ }^{5}$ Dionysius of Halicarnassus. The Roman antiquities of Dionysius of Halicarnassus ; transl. by Earnest Cary, red. Edward Spelman.- London : William Heinemann Ltd., 1937. Vol. V. - P. 156.

${ }^{6}$ Сергеев В. С. История Древней Греции ; изд. третье, перераб. и доп. / В. С. Сергеев ; под ред. В. В. Струве, Д. П. Каллистова. - М. : Изд-во восточной лит-ры, 1963. - С. 310. 
in Nubia ${ }^{7}$. The Treaty of Orihuela (Theodemir Treaty) (713 A.D.) had a similar meaning. It was agreed between the Ruler of North Africa Abd al-Aziz and Prince of Murcia Theodemir on the surrender of a number of Christian cities in Spain and their transfer to the control of the Arabs, which was of great importance as a precedent for the further cultural development of the population concerned ${ }^{8}$.

In Medieval Europe, under the conditions of popes`and emperors` claims for world domination, education issues were for a long period determined by their unilateral acts, which were objectively supranational, especially in the conditions of the development of the feudal system. In this context the Encyclica de litteris colendis, provided by Emperor Charlemagne in 787 to the monasteries of Europe is notable.

The Capitulary states that in episcopalities and monasteries, "except for the observance of rules, monastic life, and religious exercises, the reflections on the sciences were approached, according to one`s own ability to learn", because "everyone must first study what he wants to give an effect to". The document was credited with "not neglecting scientific pursuits, but to endeavor diligently to study them with all humility and good intentions before God," and "to choose people for such a purpose who would have the ability and desire to learn, and the desire to teach the others" ${ }^{9}$.

In this context, the Charlemagne Capitulary (802) is also of great interest. Henderson defined it as a founding act of the Holy Roman Empire, that is, as a document that had the features of a supranational regulator, as well as a general program for the development of state entities that are part of a single European civilization. Article 10 of the Capitulary states a requirement for bishops and priests to "teach others" the ecclesiastical canons ${ }^{10}$.

Researchers in the history of the Middle Age underline the fact that the system of organized education, emerged spontaneously, through pilgrimages to "some educational centers" such as Bologna, Paris, and others. Thus, the main impetus for self-organization of teachers and students was the issue of lack of security and minimum social standards, hostile attitude of local secular and ecclesiastical authorities.

Such self-organization in the association (Universitas, that is, universities) has led to the aspirations of the newly formed schools to obtain

${ }^{7}$ Spaulding J. Medieval Christian Nubia and the Islamic World: A Reconsideration of the Baqt Treaty / Jay Spaulding // The International Journal of African Historical Studies. - 1995. Vol. 28. - № 3. - P. 589.

${ }^{8}$ Rosenwein B. H. Reading the Middle Ages: Sources from Europe, Byzantium, and the Islamic World / Barbara H. Rosenwein ; 3d ed. - Toronto, University of Toronto Press, 2018. - P. 94.

${ }^{9}$ Стасюлевич М. М. История средних веков в ее писателях и исследованиях новейших ученых. - СПб. : Тип. М.М. Стасюлевича, 1864. - Т. II. - С. 52.

${ }^{10}$ Henderson E. F. Select Historical Documents of the Middle Ages / Ernest F. Henderson. London : George Bell and Sons, 1903. - P. 193-194. 
confirmation of their own corporate identity from the highest (and often supranational) power while maintaining internal autonomy and self-government in all matters. The authors of the XX century acknowledged that the objective importance of schools (universities) led them to be recognized by the highest political forces with the desire to use them in their own interests ${ }^{11}$.

G.I. Lipatnikova cited the Acts of Pope Honorius III concerning the fostering of the "friendships" of the University of Bologna in 1217-1224 and on the contrary, the prohibition of the "nations" of the University of Paris in 1222 and 1225. The facts of this Pope`s direct intervention in the affairs of the high school of the states of Europe "through the head" of local authorities more than 80 times in 10 years of his own pontificate are provided. His successor, Gregory IX in 1227-1241, issued more than forty acts on university affairs, and Pope Alexander IV approved almost 90 acts on these issues during $1254-1261^{12}$.

At the same time, the highest secular authorities tried to regulate the issues of university education, as evidenced by acts of the power of kings and emperors. For example, the letter of Emperor Frederick Barbarossa addressing the students and teachers of Bologna schools in 1158 provides for the protection of students and professors who "travel for the sake of knowledge" so that "they and their envoys can safely travel to the places where they are being improved in science, and quietly live there.” It was especially forbidden to apply to students the reprisals for the "debts" of other persons of the locality from where the students came to study; Jurisdiction over court cases involving students and professors was referred to the bishops of the respective cities or to another court by the choice of university representatives.

Similar privileges at the national level were granted to the students of the University of Paris by the privilege of King Philip II of France in 1200. At the same time, third-country kings appealed to self-organized schools with a call for cooperation. In this context, a letter from King Henry III of England to the "masters and university students of Paris" (1229) inviting the university to move to England with the provision of "freedom and tranquility that would satisfy your needs completely" is of great interest. The reason for the invitation was the fact that the University in Paris was "under the rule of unjust law"13.

However, in this situation, it was the acts of the popes regarding the universities that had a greater international dimension than the secular power, which at that time often opposed the church. The popes, on the one hand, used to treat their own education workers with the supranational authority, on the

${ }^{11}$ Документы по истории университетов Европы XII-XV вв. : Учеб. пособие / под ред. и с предисл. А. Е. Москаленко ; вступ. статья, пер. и примеч. Г. И. Липатниковой. Воронеж : Воронежский пед. ин-т, 1973. - С. 15-17.

${ }^{12}$ Ibid. - C. 18.

${ }^{13}$ Ibid. - C. 109-113. 
other - used their own exclusive prerogative of the organization of teaching religious disciplines in the universities. In addition, the popes as feudal lords often considered the nobility of universities, including the clergy as their own vassals and provided them with appropriate guarantees.

For example, a letter from Pope Innocent III to masters and students of Paris schools (1205) mentions a request by the Emperor of the Baldwin Empire to involve Western scholars to the "reform of Scripture teaching" in captured Byzantium. In his letter, Innocent III called for masters and students to travel to Greece to meet the emperor's appropriate needs ${ }^{14}$.

It should also be mentioned that the confirmation by the papal authority, as a supranational, of the legal status of the university, often occurred within a relatively short period of time after the granting the rights to higher education by the state authorities. Thus, the status of the University of Salamanca was granted by the King of Castile and Leon Alfonso X in 1252 and was confirmed by Pope Alexander IV in 1254. The Royal Charter on the establishment of the University of Coimbra in Lisbon was granted on March 1, 1288, and the Papal Bull of Nicholas IV on the status of this university was granted on August 9, 1288. For other universities, the time for interstate and papal recognition could take longer; for example, the University of Florence was founded as a Studium Generale by the authorities of the republic in 1321, and Pope Clement VI confirmed the rights of this institution in $1349^{15}$.

The University of Santiago de Compostela was opened in 1495, in 1504 its opening was confirmed by Pope Julius II, and the privilege bull of this university was granted by Pope Clement VII in 1526. The first Asian University of Saint Thomas was established in Manila by the Charter of Philip III of Spain in 1611 with the granting a bull of Pope Innocent X to a school, as a papal university, on November 20, 1645. Other high schools had a very significant gap between state and papal recognition; for example, the University of Alcala was founded by King of Castile Sancho IV in 1293, and the papal bull with the recognition of status and privileges was received by the institution only in 1499.

At the same time, many universities were founded by popes on their own initiative, pending the approval of relevant decisions by public authorities. For example, the University of Glasgow was founded by the papal bull in 1451, and the University of Uppsala was established by the bull of Pope Sixtus IV in 1477, granting the privileges similar to the University of Bologna to the newly established school. The Pope's Bull on the foundation of

14 Документы по истории университетов Европы XII-XV вв. : Учеб. пособие / под ред. и с предисл. А. Е. Москаленко ; вступ. статья, пер. и примеч. Г. И. Липатниковой. Воронеж : Воронежский пед. ин-т, 1973. - С. 116.

${ }^{15}$ List of oldest universities in continuous operation / Wikipedia, the free encyclopedia [Electronic source]. - Available at: https://en.wikipedia.org/wiki/List_of_oldest_universities_ in_continuous_operation. 
the Royal College of Scotland, which preceded the University of Aberdeen, was granted in $1495^{16}$.

The internal conditions of the universities gradually became regulated by the papal authority in a quite thorough manner. For instance, the decree of the papal legate of Robert de Curson on students and masters of Paris schools in 1215 established mandatory requirements for lecturers in liberal arts. These are the minimum age, good faith, educational experience, minimum teaching term, passing the exam, and the order of holding lectures.

It was stated that the examination of teachers should be taken by special judges appointed by the pope according to the form approved by the bishop of Paris. The following procedure for such examinations was clarified by Pope Gregory IX's bull for the University of Paris on April 13, 1231. According to this bull, the Chancellor of Paris was entrusted with the function of checking the integrity of the candidate for teaching, with providing the university with guarantees of arbitrariness in this process (special oath of the Chancellor, involvement of all masters of theology of the university in the examination) ${ }^{17}$.

The Bull of Gregory IX from April 13, 1231, is also noteworthy. It confirmed not only the autonomy of the University of Paris but also the right to strike against the city government, as well as the decision of Pope Boniface VIII in 1301, that supported the position of students of the University of Bologna in a dispute with the city authorities, that required the rector to pledge allegiance ${ }^{18}$.

It is also necessary to point out the privilege that was granted on September 22, 1255, by Pope Alexander IV to "the University of the Masters and Students in Salamanca". In this act, persons who "passed the examination and were approved at the University of Salamanca" at a certain faculty were subsequently given the right to teach, without taking new exams and " anyone`s resisting" at a similar faculty at any other university except the Paris and Bologna. According to G.I. Lipatnikova, such a right to teach (ius ubique docendi) for the masters of a number of universities were granted by the popes "using the universal character of their own power", with universities often being discriminated ${ }^{19}$.

Thus, the masters of the University of Cambridge were one of the last to be granted such a right, in 1318, and the University of Oxford did not receive such a right at all. Such privilege of Pope Nicholas IV for "University

${ }^{16}$ List of oldest universities in continuous operation / Wikipedia, the free encyclopedia [Electronic source]. - Available at: https://en.wikipedia.org/wiki/List_of_oldest_universities_ in_continuous_operation.

${ }^{17}$ Документы по истории университетов Европы XII-XV вв. : Учеб. пособие / под ред. и с предисл. А. Е. Москаленко ; вступ. статья, пер. и примеч. Г. И. Липатниковой. Воронеж : Воронежский пед. ин-т, 1973. - С. 116.

${ }^{18}$ Ibid. - C. 122.

${ }^{19}$ Ibid. - C. 17. 
of Masters and Students of Paris" was granted on March 23, 1292, confirmed the papal "power to give the right to teach" and defined the universal nature of the examination of the University of Paris teachers (masters) of the faculties of theology, canon law, medicine, and liberal arts that could lecture anywhere "beyond this city and the faculty" after its passing. The customs and statutes that prevented this privilege were defined in it as invalid ${ }^{20}$.

At the same time, it is worth mentioning such key legal acts of secular power of the XIII century that reflected rights, including educational ones, such as the Magna Carta $(1215)^{21}$, as well as the Golden Charter of Bern (1218) and the Privileges of Vienna (1237), granted by Emperor Frederick II Hohenstaufen. In the Golden Charter, the Emperor guaranteed the eternal refusal from the appointment of a teacher of the church school; the imperial authorities undertook to approve the candidate proposed by the city authorities with the common consent (communi consilio) of the candidate. In the Privilege (1237) "going towards the common desire to teach children from a young age" the right of a master's imperial authority, the head of a school in Vienna, "to appoint, with the consent of the most conscious men of this city, other doctors in the faculties, worthy and respected in the field of their sciences" was stated ${ }^{22}$.

It is interesting that the apparent increase in the common desire of European societies for education at that time was also reflected in trade agreements. Thus, in the draft trade agreement of the Novgorod Republic with the free cities of Lubeck and Gotland, which was handled by the parties in 1268-1269 years in XIII century, the right of merchants of these German cities to "freely send their children to learn the language of the land they want" during their stay in Novgorod was envisaged ${ }^{23}$.

A striking example of the further regulation of educational relations in European states is the establishment of the University of Prague by the Bull of Pope Clement VI on January 26, 1347. The document referred to a previous proposal (request) on this issue by Emperor Charles I (IV) stating the absence of "a higher school, while there is a great need for it " in the Czech Kingdom "as well as in many neighboring countries". The Bull indicated the universal competence of the popes in "helping", " those faithful who show interest in the pursuit of the teachings glorifying God, strengthening the Catholic faith

20 Документы по истории университетов Европы XII-XV вв. : Учеб. пособие / под ред. и с предисл. А. Е. Москаленко ; вступ. статья, пер. и примеч. Г. И. Липатниковой. Воронеж : Воронежский пед. ин-т, 1973. - С. 17, 120.

21 Ясинский А. История Великой Хартии в ХІІІ столетии / А. Ясинский // Киевские университетские известия. - К. : Унив. тип-я, 1888. - № 7. - С. 34.

${ }^{22}$ Средневековое городское право XII-XIII веков : сборник текстов / под ред. С. М. Стама. - Саратов : Изд-во Сарат. ун-та, 1989. - С. 45, 47.

${ }^{23}$ Рыдзевская Е. А. Новый список проекта договора Новгорода с Любеком и Готландом 1269 г. // Проблемы истории докапиталистических обществ. - Л. : 1935. № 5-6. - C. 121. 
and ensuring justice and success in public and private affairs and the prosperity of the whole human race" under appropriate circumstances ${ }^{24}$.

Clement VI noted that since Prague is "rich in necessities for life", this city "is a fairly suitable place for higher education, although there are only private schools." The Bull of 1347 indicated the will of the pope for "the cause of science for the wealthy population endowed with all kinds of goods" and noted that "along with gold and silver mines scientific mine should be established" in the Czech Kingdom. The Bull emphasized the need for "men from this kingdom who were taught by the maturity of thought, adorned with virtues and scholars in various fields trained in the understanding of the tenets of faith", the need to establish a "source from which all who seek knowledge of the essence of written education could draw" ${ }^{\prime 25}$.

In the Bull of 1347, Clement VI stated that " the university in Prague and all permitted faculties is to prosper" forever, drawing on his own "apostolic law". At the same time, the Bull was to provide the teachers and students of the newly formed university with "rights, privileges, and expulsions from the general jurisdiction following the suit of doctors, masters, and students of other universities", that is, apparently, based on the established supranational custom at that time. The Bull stated that in order to obtain the status of master or doctor, the applicant had to be represented by the masters of the respective faculty in front of the Archbishop of Prague. Thereafter, the archbishop had to convene doctors and masters of this faculty and instruct them to carry out "a thorough examination in the sciences that are necessary for doctoral or master's honor degree" ${ }^{26}$.

The Bull of 1347 stated that "if the answers of the subjects of examination are considered as sufficient, the archbishop gives them the right of teaching and recognizes their the honor and degree of master". The exam was also given the status of a universal, providing the graduate with the right to teach at any other university. However, the royal charter of Charles I (IV) on the foundation of the University of Prague, which mentioned the precedents of higher educational establishments in Paris and Bologna, was granted only on April 7, $1348^{27}$.

At the same time, the state authorities and popes sometimes negotiated the establishment of the university and the extent of its privileges to issue acts on its establishment. For instance, the University of Heidelberg was established by an act of the Duke of Bavaria and Prince of the Holy Roman Empire Rupert I in October 1386, under the conditions of a preliminary

${ }^{24}$ Документы по истории университетов Европы XII-XV вв. : Учеб. пособие / под ред. и с предисл. А. Е. Москаленко ; вступ. статья, пер. и примеч. Г. И. Липатниковой. Воронеж : Воронежский пед. ин-т, 1973. - С. 131.

${ }^{25}$ Ibid. - C. 132.

${ }^{26}$ Ibid. - C. 133.

${ }^{27}$ Ibid. - C. 131. 
positive decision on the subject by the pope, approved in 1386 without the publication of the Bull. Under the agreement of the Duke and Pope, the university was to receive privileges similar to the University in Paris.

In the act on establishment, the Duke determined the number and the names of four faculties - "the first one, of theology; the second one, of canon and civil law, which are appropriate to be formed into a single faculty because of their similarity; the third one, the faculty of medicine, and the fourth one, of liberal arts", and declared the work of the institution of "four nations", granting all privileges, "even with more generosity", to all university staff, including "overseers, librarians, servants, parchment makers, scribes and illustrators" etc. ${ }^{28}$.

It is important to cite the provisions of the Concordat (treaty) agreed between Pope Leo X and the King of France Francis I in Bologna in December 1515 and in Rome on 16 August 1516. This Bologna Concordat governed the appointment of higher church posts in France, abolished previous acts and established a compromise according to which the pope had the authority to appoint bishops and abbots but solely from candidates proposed by the king. In Concordat, it was specifically required that a candidate proposed for approval by a king to the pope had to be a "Master or Licentiate of Theology or a Doctor or Licentiate of all or one of the universities, which is famous for its rigorous examinations" ${ }^{29}$. However, the Concordat did not list such universities, by its definition it included graduates of the University of Paris, the University of Bologna, and other universities.

As it was already noted, a similar approach to the formation of universities prevailed in the colonies of the European states. It is noteworthy that the first university of the New World in Santo Domingo (the Dominican Republic now) was founded by the Bull of Pope Paul III in Apostolatus Culmine from October 28, 1538, granting it the authority similar to the Spanish University of Alcala, and the establishment of four universities that were traditional for then higher schools.

The Royal Decree (Charter) confirming the rights of this institution was given twenty years later, in 1558, with the naming of the institution as the University of St. Thomas Aquinas. The process of the establishment of the institution may be explained by the formation of a university on the seminary basis (Studium Generate) of the Dominicans, which has operated on the island since 1518, as a structure from the outset oriented on the church rather than on the secular power ${ }^{30}$.

${ }^{28}$ Henderson E. F. Select Historical Documents of the Middle Ages / Ernest F. Henderson. - London : George Bell and Sons, 1903. - P. 262-267.

${ }^{29}$ Хрестоматия по истории средних веков ; пособие под. ред. Н.П. Грацианского, С.Д. Сказкина в 3 томах. - Т. 3. - М. : Учпедгиз, 1950. - С. 35.

${ }^{30}$ Universidad Santo Tomás de Aquino / Wikipedia, the free encyclopedia [Electronic source]. - Available at: https://en.wikipedia.org/wiki/Universidad_Santo_Tomás_de_Aquino. 
The next University of the American continent was founded in Lima (now Peru) by decree of the Spanish King (Emperor) Charles I from May 12, 1551, as the "General School and Real University of the Royal City", granting an institution the privileges similar to the status of University of Salamanca; this decree was confirmed by the Bull of Pope Pius V from July 25, 1571, which confirmed the conditions under which the emperor founded the university "under the rules of royal patronage" ${ }^{31}$.

Later, in Sucre ( Bolivia), the Royal and Pontifical Major University of St. Francis Xavier de Chuquisac was established, which was due to the proclamation of the Royal Act (Charter) by Philip III on 2 February 1622 and by the Bull of Pope Gregory XV on August 8, 1623; the university has been operating since $1624^{32}$.

Subsequently, in the context of the Reformation, the role of popes in regulating aspects of education declined; at the same time, in supranational legal acts, the regulation of education was implemented through the measure of ensuring the protection of religious freedoms. Thus, the Ausburg religious agreement from September 25, 1555, between Catholic and Lutheran entities of the Holy Roman Empire on behalf of the emperor Roman King Ferdinand I established a balance between the territories of Catholicism and Protestantism, guaranteeing the appropriate educational rights.

Thus in Article 19 of the agreement from 1555 guaranteed the preservation of the new status of the individual abbeys, monasteries and other church estates seized during the religious wars and converted, "into schools and charitable institutions" 33 . The provisions of the agreement in this paragraph were confirmed, inter alia, by the Peace of Prague ( May 30, 1635) between Emperor Ferdinand II and the representative of the Protestant states of the empire, Johann George I ${ }^{34}$.

It is necessary to add that in Article 8 of the Treaty of Vienna, agreed on June 23, 1606, between the Prince of Transylvania and the Archbishop of Austria, prohibited the activities of the Jesuits in Hungary ${ }^{35}$. At the same time, the Madrid Treaty (1621), agreed on the guarantees of the King of France and the Swiss Confederation, provided for freedom of religion and related

${ }^{31}$ Universidad Nacional Mayor de San Marcos / Historia [Electronic source]. - Available at: http://www.unmsm.edu.pe/home/inicio/historia.

${ }^{32}$ Universidad San Francisco Xavier de Chuquisaca 1624 - 2018 / Historia [Electronic source]. - Available at: https://www.usfx.bo/principal/historia/.

${ }^{33}$ European treaties bearing on the history of the United States and its dependencies to 1648 ; ed by Frances G. Davenport, Charles O/ Paullin,. - Washington, D.C. : Carnegie Institution of Washington, 1917. - P. 44.

${ }^{34}$ The Low Countries in Early Modern Times: A Documentary History ; ed by Herbert H. Rowen. - New York : Palgrave Macmillan, 1972. - P. 16.

${ }^{35}$ Sugar P. F. A History of Hungary / Peter F. Sugar, Peter Hanák, Tibor Frank. - L. : Indiana University Press, 1990. - P. 97. 
enlightenment and educational activities in the disputed Alpine valley of Valtellina ${ }^{36}$.

It is important to mention the consequences of the French authorities' approval of the Edict of Nantes (April 13, 1598) in Article 13 of which the manifestation of Protestantism in various spheres of public life, in particular as regards "public education" is prohibited. Also, Article 22 of this edict imposes a prohibition of discrimination against Protestants in the field of "admission of students to the universities, colleges, and schools." The following provisions of the Edict of Nantes were confirmed in the Treaty of Montpellier (18 October 1622) between King of France Louis XIII and Duke Henry II of Rohan, as well as in the Treaty of Alaska agreed on June 28, 1629, between King of France Louis XIII and Huguenots leaders ${ }^{37}$.

It would also be appropriate to add that in the series of treaties which together formed the system of the Peace of Westphalia (the Treaty of Münster of 15 May 1648, the Treaty of Osnabrück of 24 October 1648), the issue of education was not specifically mentioned; these acts only indirectly affected the relationship within the framework of guaranteeing freedom of confession for Catholics, Lutherans, and Calvinists ${ }^{38,} 39,40$. In general, one can say about a system of international peace treaties of the XVII-XVIII centuries that reflected the conditions of the Treaty of Westphalia with regard to education, as it follows, for example, from the Treaty of Versailles of September 3, $1783^{41}$.

The institute of preserving and returning the archives of various institutions after the end of the inter-state armed conflict was important in this contractual practice. This institute, which, of course, extended to universities, was introduced in Article 22 of the Peace and Friendship Treaty between the Kings of Britain, France, Spain and Portugal of February 10, $1763^{42}$.

Special attention should be paid to the development of international treaty support for educational relations in Ukrainian territory, a reference to which can be found in the documents of the liberation contest period in XVII century. Until that period, the educational aspects of the states, which

${ }^{36}$ European treaties bearing on the history of the United States and its dependencies to 1648 ; ed by Frances G. Davenport, Charles O / Paullin,. - Washington, D.C. : Carnegie Institution of Washington, 1917. - P. 116.

${ }^{37}$ Ibid. - P. 259.

${ }^{38}$ Ibid. - P. 12.

${ }^{39}$ The Low Countries in Early Modern Times: A Documentary History ; ed by Herbert H. Rowen. - New York : Palgrave Macmillan, 1972. - P. 181.

${ }^{40}$ Дмитрієв А.I. Вестфальський мир 1648 року і сучасне міжнародне право : монографія / Анатолій І. Дмитрієв. - К. : Київський університет права, 2001. - С. 210.

${ }^{41}$ Treaties of Versailles, 3 September 1783 [Electronic source]. - Available at: https://www.heraldica.org/topics/france/utrecht.htm.

${ }^{42}$ The definitive Treaty of Peace and Friendship between his Britannick Majesty, the Most Christian King, and the King of Spain. Concluded at Paris the 10th day of February, 1763. To which the King of Portugal acceded on the same day [Electronic source]. - Available at: http://avalon.law.yale.edu/18th_century/paris763.asp. 
included the territory of Ukraine, were not regulated separately in foreign acts. For example, in the text of the Union of Lublin, agreed on 1 July 1569, namely in its Article 7 can be found only a general mention of the preservation of the privileges granted in the newly formed state, which should obviously include the princely and royal acts concerning the establishment of universities and colleges ${ }^{43}$.

At the same time, virtually all the key acts concluded by the Ukrainian side with the Crown of the Kingdom of Poland and the Grand Duchy of Lithuania contained provisions on education issues. Thus, the Article 10 of the Treaty of Zboriv, agreed on August 1649, contained injunctions prohibiting the activities of Jesuits, including educational "in Kyiv, where privileged schools of Rus are based ... and in other Ukrainian cities", while at the same time all "other schools" that had been there "since the dawn of time" were to be preserved ${ }^{44,45}$. In Article 6 of the Treaty of Bila Tserkva (September 28, 1651) the preservation of the rights of the Orthodox religion "according to ancient rights", which included "cathedrals, churches, monasteries, and the Kyiv Collegium" was stated ${ }^{46}$.

In the Hadiach Treaty of September 16, 1658, the issues of education were regulated in a more thorough manner. According to this act, the "Academy of Kyiv" was granted the "prerogatives and liberties" equal to the "Academy of Krakow" prerogatives and liberties (i.e. Krakow University) by royal authorities, but only under the condition that it did not present "Arian, Calvinist, Lutheran professors, teachers, and students". The treaty also agreed on the transfer of all other schools "that had been in Kyiv before" (apparently referring to Jesuit schools) to another place by the decision of the royal authority ${ }^{47}$.

The Hadyach Treaty provided for the establishment of a second academy in Ukraine, which should have had the same rights as the Kyiv one, where the royal authorities and the Sejm would "see a suitable place for it", and also under the condition that the Protestants were not admitted and the were no other schools in its place. In contrast to the aforementioned academies, the treaty allowed to freely open "high schools, collegiums,

${ }^{43}$ Из постановления Люблинского сейма об унии Великого княжества Литовского с Короной Польской 1 июля 1569 г. // Белоруссия в эпоху феодализма. Сборник документов и материалов ; под ред. А.И. Азарова и др. - Т. І. - Минск : Изд-во АН БССР, 1959. - С. 153.

44 Акты, относящиеся к истории Южной и Западной России, собранные и изданные Археографической комиссией. - Т. 3 : 1638-1657. - СПб. : Тип. П. А. Кулиша, 1861. - C. 125.

45 Яковлів А. Українсько-московські договори XVII - XVIII ст. / Андрій Яковлів. Варшава : Наук. т-во ім. Шевченка, 1934. - С. 46.

${ }^{46}$ Горобець В. М. Білоцерківський договір 1651 р. / В. М. Горобець // Енциклопедія історії України : у 10 т. / редкол. В. А. Смолій та ін. - К. : Наукова думка, 2003. - Т. 1. A-B. - C. 292.

47 Горобець В. М. Гадяцький договір 1658 р. / В. М. Горобець // Енциклопедія історії України : у 10 т. / редкол.: В. А. Смолій та ін. - К. : Наукова думка, 2004. - Т. 2. Г-Д. - С. 14. 
schools and printing houses" in Ukraine and "to print books of any kind with religious conversion", but without criticism of the royal authorities ${ }^{48,49}$.

It is interesting that the agreements of the Ukrainian authorities of that period with the Tsardom of Muscovy did not regulate educational issues at all, despite the incorporation of these aspects into the proposals to such agreements by the Ukrainian side. Thus, in the draft of the new interstate agreement proposed by representatives of the Cossack officers to the Tsardom of Muscovy in October 1659 (Zherdivsky articles), "free existence of schools with any language of teaching on both banks of the Dnipro river" was envisaged, which was not taken into account by the royal authorities ${ }^{50}$.

In general, the issue of higher education was repeatedly mentioned in the then interstate treaties on the change of territory or status of the country, in particular, the country could be given certain guarantees. For example, the Acts (Treaty) of Union with Scotland, ratified by the parliaments of England and Scotland in 1706, contained a special prescription on the regulation stated in Article 25 on the termination of legal sources that are contrary to the Act, after the merger of two states; under this prescription, "the universities and colleges of St. Andrew, Glasgow, Aberdeen, and Edinburgh continue to operate" ${ }^{51}$.

However, such treaty regulations were not always respected by the states; in particular, in Article 10 of the Treaty of Nyshtad between Russia and Sweden (August 30,1721), Russia undertook, inter alia, to keep schools that remained in the territory of Baltic States, transmitted by Sweden, and in Article 4 - archives of the respective lands (archives and documents evacuated to Sweden should be returned to the institutions).

At the same time, the second university of Sweden, established in Dörpt (now Tartu, Estonia) by King Gustav II Adolf in 1632 as Academia Gustaviana (later - Universitas Gustaviana), was located on the lands given to Russia. The regulations of the Treaty of Nyshtad were not respected in this institution; it has ceased to exist under the conditions of Russian occupation in 1710 and was not re-established in peacetime; the university in this city has started its operation only since 1802, and the university archives of the Swedish period were not preserved ${ }^{52,53}$.

${ }^{48}$ Акты, относящиеся к истории Южной и Западной России, собранные и изданные Археографической комиссией. - Т. 3 : 1638-1657. - СПб. : Тип. П. А. Кулиша, 1861. - 604 с.

${ }^{49}$ Горобець В. М. Гадяцький договір 1658 р. / В. М. Горобець // Енциклопедія історії України : у 10 т. / редкол.: В. А. Смолій та ін. - К. : Наукова думка, 2004. - Т. 2. Г-Д. - С. 14.

50 Яковлів А. Українсько-московські договори XVII-XVIII ст. / Андрій Яковлів. Варшава : Наук. т-во ім. Шевченка, 1934. - С. 77.

51 Union with Scotland Act 1706 [Treaty of Union, took effect on 1 May 1707] [Electronic source]. - Available at: http://www.legislation.gov.uk/aep/Ann/6/11/contents.

${ }^{52}$ List of oldest universities in continuous operation / Wikipedia, the free encyclopedia [Electronic source]. - Available at: https://en.wikipedia.org/wiki/List_of_oldest_universities_ in_continuous_operation. 
The regulations of Article 23 of The Treaty of Amity and Commerce between the United States of America and Kingdom of Prussia (September 10, 1785), which reflected progressive for that time understanding of the law of war and provided a list of non-combatants who had received warranties from both states in the event of war between them are also of a great interest; this list also included "scholars of every faculty".

According to this regulation, such scholars (students) should be allowed to study and they cannot be molested personally if they are unarmed and live in a non-fortified city, settlement or another place during the war. Their homes and property cannot be burned out and destroyed, their fields cannot be devastated with the enemy forces. If due to the war, such scholars (students) have something withdrawn for military needs, they should receive monetary compensation at a reasonable $\operatorname{cost}^{54}$.

\section{CONCLUSIONS}

Accordingly, the following conclusions are reached. In antiquity, international legal acts paid indirect attention to the aspects of the exercise of the right for education and the organization of education systems. In the Middle Ages, the emergence and development of the university education system became the subject of legal support of supranational regulators, primarily the acts of Popes of a universal nature.

The establishment or recognition of the universities that had been formed on the initiatives, the establishment of guarantees of their autonomy, ensuring mutual recognition of the results of the master's and doctoral examinations, the requirements of having such titles for religious positions were the main issues of supranational security.

The recognition of education in international acts as one of the key guarantees of the exercise of religious rights emerged in the Middle Ages and was formed during the Reformation. The agreements of the Ukrainian authorities during the period of national liberation competitions of the $17^{\text {th }}$ century, which consistently uphold the need to develop the national secondary and higher education system are of particular importance. The issues mentioned must form the basis for new scientific research.

${ }^{53}$ Ништадтский мирный договор между Россией и Швецией 30 августа 1721 г. [Electronic source]. - Available at: http://www.hrono.ru/dokum/1700dok/1721nishtadt.php.

${ }^{54}$ Treaties of Versailles, 3 September 1783 [Electronic source]. - Available at: https://www.heraldica.org/topics/france/utrecht.htm. 


\section{SUMMARY}

The article reflects the evolution of the international promotion of the regulation of the educational issues in the Ancient and Middle Ages. Special attention was devoted to the issues of the international legal framework of the first European universities`activities, of the treaties fixing of the educational components of interreligious relations, of the treaties guaranteeing the development of the Ukrainian educational system at the times of liberating struggle during XVII century.

\section{REFERENCES}

1. Dionysius of Halicarnassus. The Roman antiquities of Dionysius of Halicarnassus ; transl. by Earnest Cary, red. Edward Spelman.- London : William Heinemann Ltd., 1937. - Vol. V. - 408 p.

2. European treaties bearing on the history of the United States and its dependencies to 1648 ; ed by Frances G. Davenport, Charles O. / Paullin,. Washington, D.C. : Carnegie Institution of Washington, 1917. - $400 \mathrm{p}$.

3. Henderson E. F. Select Historical Documents of the Middle Ages / Ernest F. Henderson. - London : George Bell and Sons, 1903. - 540 p.

4. List of oldest universities in continuous operation / Wikipedia, the free encyclopedia [Electronic source]. - Available at: https://en.wikipedia.org/ wiki/List_of_oldest_universities_in_continuous_operation

5. Rosenwein B. H. Reading the Middle Ages: Sources from Europe, Byzantium, and the Islamic World / Barbara H. Rosenwein ; 3d ed. - Toronto, University of Toronto Press, 2018. - 568 p.

6. Spaulding J. Medieval Christian Nubia and the Islamic World: A Reconsideration of the Baqt Treaty / Jay Spaulding // The International Journal of African Historical Studies. - 1995. - Vol. 28. - № 3. - P. 577-594.

7. Sugar P. F. A History of Hungary / Peter F. Sugar, Peter Hanák, Tibor Frank. - L. : Indiana University Press, 1990. - 448 p.

8. The definitive Treaty of Peace and Friendship between his Britannick Majesty, the Most Christian King, and the King of Spain. Concluded at Paris the 10th day of February, 1763. To which the King of Portugal acceded on the same day [Electronic source]. - Available at: http://avalon.law.yale.edu/18th_century/paris763.asp.

9. The Low Countries in Early Modern Times: A Documentary History ; ed by Herbert H. Rowen. - New York : Palgrave Macmillan, 1972. - 271 p.

10. Treaty of Amity and Commerce Between His Majesty the King of Prussia, and the United States of America; September 10, 1785 [Electronic source]. - Available at: http://avalon.law.yale.edu/18th_century/prus1785.asp.

11. Treaties of Versailles, 3 September 1783 [Electronic source]. Available at: https://www.heraldica.org/topics/france/utrecht.htm. 
12. Union with Scotland Act 1706 [Treaty of Union, took effect on 1 May 1707] [Electronic source]. - Available at: http://www.legislation.gov.uk/ aep/Ann/6/11/contents.

13. Universidad Nacional Mayor de San Marcos / Historia [Electronic source]. - Available at: http://www.unmsm.edu.pe/home/inicio/historia.

14. Universidad San Francisco Xavier de Chuquisaca 1624-2018 / Historia [Electronic source]. - Available at: https://www.usfx.bo/principal/ historia/.

15. Universidad Santo Tomás de Aquino / Wikipedia, the free encyclopedia [Electronic source]. - Available at: https://en.wikipedia.org/ wiki/Universidad_Santo_Tomás_de_Aquino.

16. Акты, относящиеся к истории Южной и Западной России, собранные и изданные Археографической комиссией. - Т. 3 : 1638-1657. СПб. : Тип. П. А. Кулиша, 1861. - 604 с.

17. Белох К. Ю. Греческая история в 2 томах / Карл Ю. Белох ; пер. с нем. М. О. Горшензона ; под ред. Ю. И. Семенова. - М., 2009. - Т. 1: Кончая софистическим движением и Пелопоннесской войной. $-512 \mathrm{c}$.

18. Горобець В. М. Білоцерківський договір 1651 p. / В. М. Горобець // Енциклопедія історії України : у 10 т. / редкол. В. А. Смолій та ін. - К. : Наукова думка, 2003. - Т. 1. А-В. - С. 292.

19. Горобець В. М. Гадяцький договір 1658 р. / В. М. Горобець // Енциклопедія історії України : у 10 т. / редкол.: В. А. Смолій та ін. - К. : Наукова думка, 2004. - Т. 2. Г-Д. - С. 14.

20. Дмитрієв А.І. Вестфальський мир 1648 року i сучасне міжнародне право : монографія / Анатолій І. Дмитрієв. - К. : Київський університет права, 2001. - 426 с.

21. Документы по истории университетов Европы XII-XV вв. : Учеб. пособие / под ред. и с предисл. А. Е. Москаленко ; вступ. статья, пер. и примеч. Г. И. Липатниковой. - Воронеж : Воронежский пед. ин-т, 1973. - $157 \mathrm{c}$.

22. Евсеенко Т П. От общины к сложной государственности в античном Средиземноморье / Тимур П. Евсеенко. - СПб. : Юрид. центр Пресс, 2005. - 264 c.

23. Из постановления Люблинского сейма об унии Великого княжества Литовского с Короной Польской 1 июля 1569 г. // Белоруссия в эпоху феодализма. Сборник документов и материалов ; под ред. А. И. Азарова и др. - Т. І. - Минск : Изд-во АН БССР, 1959. - С. 150-157. 24. Ништадтский мирный договор между Россией и Швецией 30 августа 1721 г. [Electronic source]. - Available at: http://www.hrono.ru/ dokum/1700dok/1721nishtadt.php. 
25. Рыдзевская Е. А. Новый список проекта договора Новгорода с Любеком и Готландом 1269 г. // Проблемы истории докапиталистических обществ. - Л. : 1935. - № 5-6. - С. 119-125.

26. Сергеев В. С. История Древней Греции ; изд. третье, перераб. и доп. / В. С. Сергеев ; под ред. В. В. Струве, Д. П. Каллистова. - М. : Изд-во восточной лит-ры, 1963. - 516 с.

27. Средневековое городское право XII-XIII веков : сборник текстов / под ред. С. М. Стама. - Саратов : Изд-во Сарат. ун-та, 1989. - $178 \mathrm{c}$.

28. Стасюлевич М. М. История средних веков в ее писателях и исследованиях новейших ученых. - СПб. : Тип. М.М. Стасюлевича, 1864. - T. II. -690 c.

29. Хрестоматия по истории средних веков ; пособие под. ред. Н.П. Грацианского, С.Д. Сказкина в 3 томах. - Т. 3. - М. : Учпедгиз, 1950. - $350 \mathrm{c}$.

30. Щокін Ю. В. Міжполісні й міжплемінні союзи Стародавньої Греції VI-IV століть до н. е. / Ю. В. Щокін // Теорія і практика правознавства. - 2016. - Вип. 2 (10). - С. 1-13.

31. Яковлів А. Українсько-московські договори XVII-XVIII ст. / Андрій Яковлів. - Варшава : Наук. т-во ім. Шевченка, 1934. - 178 с.

32. Ясинский А. История Великой Хартии в ХІІІ столетии / А. Ясинский // Киевские университетские известия. - К. : Унив. тип-я, 1888. - № 7. -61 c.

\section{Information about the author:} Hromovenko K. V., Ph.D., Docent, Rector of the International Humanitarian University Odesa, Ukraine 